Trinity University

Digital Commons @ Trinity

Modern Languages and Literatures Faculty

Research

Modern Languages and Literatures Department

2-1989

\title{
The Portrait on Stage in Molière's Theater
}

Nina Ekstein

Trinity University, nekstein@trinity.edu

Follow this and additional works at: https://digitalcommons.trinity.edu/mll_faculty

Part of the Modern Languages Commons

\section{Repository Citation}

Ekstein, N. (1989). The portrait on stage in Molière's theater. Romance Quarterly, 36(1), 3-14. doi:10.1080/ 08831157.1989 .9932601

This Article is brought to you for free and open access by the Modern Languages and Literatures Department at Digital Commons @ Trinity. It has been accepted for inclusion in Modern Languages and Literatures Faculty Research by an authorized administrator of Digital Commons @ Trinity. For more information, please contact

jcostanz@trinity.edu. 


\title{
The Portrait on Stage in Molière's Theater
}

\author{
Nina Ekstein
}

Mais lorsque vous peignez les hommes, il faut peindre d'après nature. On veut que ces portraits ressemblent; et vous n'avez rien fait, si vous n'y faites reconnaître les gens de votre siècle.

Literary portraits, while common in a wide variety of genres, are not often thought of in connection with the stage. Discussions of dramaturgy make little mention of portraits, ${ }^{2}$ which is perhaps not surprising when one considers that theater is the domain of action, movement, and conflict; the portrait, on the contrary, is primarily descriptive. Verbal portraiture would not seem to be terribly effective in a theatrical context: it is unlikely to advance the action of the play, nor would it lend itself readily to gesture and movement. ${ }^{3}$ Theater requires the physical presence of its object, portraiture depends on a certain absence and remove. Yet portraits are indeed an element of theater, and their existence raises complex structural and dramatic issues which are well illustrated by reference to the theater of Molière.

Molière, called "le peintre" by some of his contemporaries, ${ }^{4}$ provides a large number and variety of examples of dramatic portraiture for study. The notion of character is at the core of his comedies: our memories of Tartuffe, Alceste, Harpagon, Orgon, Dom Juan, Arnolphe, and Scapin are no doubt more firmly etched than those of the particular events in which the characters are presented. Character is manifested in many different ways in theater: names, gestures, costume, acts, voice, movement, description. Portraits are only one of many sources of the spectator's impressions of a character. Thus, to talk about portraits in Molière's theater is to discuss a phenomenon whose functions and effects are shared, in part, by other forms of discourse and other semiotic systems. Yet, portraits are nonetheless a privileged form of discourse in any discussion of character. Philippe Hamon calls them "le lieu de fixation privilégié de traits descriptifs." 5 Unlike other indicators of personality and character, portraits claim to present a summation of the individual, a resume of the whole person, the most crucial traits and features which taken together are understood to represent his/her essence. 
What are the basic characteristics of the literary portrait, a genre whose roots can be traced to Homer ${ }^{6}$ and which flourished in seventeenth-century France? 1) It is a description of an individual, a unique being possessing a proper name, ${ }^{7}$ rather than a type or a category of persons. 2) The description generally includes two levels: a concrete and an abstract level. The concrete involves physical description and is conventionally understood to be linked to the abstract level, which corresponds to a moral, spiritual, or psychological plane. 3) A portrait is essentially non-narrative, although it may include brief narrative segments; it focuses on enduring traits and repeated actions rather than specific undertakings, thus favoring the present and the imperfect tenses. ${ }^{8}$

The special significance of this form to the seventeenth century can be seen in the variety of contexts in which it appeared. Portraits were common in the first half of the century in so-called "history" books, where they took the form of idealized and allegorical descriptions of historical figures. ${ }^{9}$ Richelieu made propaganda out of portraiture: from the 1620 s to the 1640 s, the Cardinal commissioned many portrait books, which elaborated and glorified the royal ideology of absolutism by depicting the political figures of the day as ancient gods and heroes. ${ }^{10}$

But the vogue of the portrait, both as literature and as a social pastime, occurred in the middle of the century. Mlle de Scudéry is generally credited for its popularity, both in literature (with her Grand Cyrus, 1649-53) and in society (in the Scudéry salon). The two are not unrelated, for the portraits in her novels are thought to depict actual persons (in Clélie, 1654-61, members of her salon; in Le Grand Cyrus, the major figures of the Fronde). As Erica Harth indicates (pp. 97, 100), to be the object of a portrait in one of her novels was a sign of social status and success.

The popularity of the portrait in the middle of the seventeenth century brought a proliferation of the genre. The Divers Portraits, written by Mlle de Montpensier and her friends (1659), traced a closed circle: each author depicted either him/herself or another member of the group. The portraits, expressions of flattery or narcissism, existed outside of any larger literary or social context. Idealized, précieux, and often extreme in their use of abstraction and superlatives, these portraits and others like them soon became the object of parody in such works as Sorel's Description de l'isle de la portraiture (1659) and Furetière's Le Roman bourgeois (1666).

The literary portrait did not, however, disappear, but rather developed, changing form and function. Literary portraitists began to focus less on the ideal and more on the tensions between the real and the apparent. In a period preoccupied by the tensions between "être" and "paraître," literary portraits often reflected an abiding concern both with recognizing the differences between the two and with arriving at a harmonious linguistic union of physical appearance and internal personality traits, approximating the truth or the essence of an individual. Consequently, portraits came to be considered as a privileged vehicle of objectivity, an artistic encapsulation of a human being. Portraits were common in such nonfictional works as the Mémoires of the Cardinal de Retz (as well as those of Saint-Simon), the letters of Mme de Sévigné, and in the funeral orations of Bossuet. ${ }^{11}$ Although we speak of the portrait as "literary," in fact portraits throughout the seventeenth century were conventionally understood to depict real individuals, at most disguised as fictional characters. This explains BussyRabutin's difficulties after the publication of his Histoire amoureuse des Gaules and the frequent pastime of suggesting keys for La Bruyère's Caractères.

Molière, as we shall see, exploits his audience's association of objectivity with the portrait. In this introduction to the portrait in Molière's theater, I will limit myself to the range of its functions, focusing primarily on the context in which portraits occur, their comic potential, and the specifically dramatic ends to which Molière employs them.

We may begin an evaluation of the portrait in Molière by examining its significance in quantitative terms. Portraits appear in approximately twothirds of Molière's plays, particularly in those which depict contemporary society. The heaviest concentration by far is found in two plays: Tartuffe and Le Misanthrope (thirteen and nineteen portraits respectively; the next highest is Le Malade imaginaire with six). The length of the portraits varies from a few lines up to thirty. Most, however, are relatively brief, in the range of six to nine lines. Over two-thirds of them describe characters who appear onstage at some point in the play, and most of these individuals play a significant role in the action. Portraits may occur at any point in a play (the denouement of Le Misanthrope is based on a series of portraits), but are generally found in the first half, and most commonly in the first act.

A brief examination of even such basic considerations leads us to questions of function. Why are portraits present at all, and what effect does their placement in the text have? Portraits, by their nature, would seem to imply a certain functional gratuity: they do not advance action directly, and they may easily stand alone, indepentent of context. Outside of the dramatic context, this potential for independence is pronounced. In the case of the portraits found in the French salons of the 1650s and 1660s, in Mlle de Montpensier's Divers Portraits, and even in the Cardinal de Retz's "galérie de portraits," the portrait constitutes a self-sufficient art form. In order to be dramatically successful, however, portraits must be neither gratuitous nor disruptive of the drama. On the contrary, they will be most dramatic when they have simultaneous onstage functions. ${ }^{12}$

In Molière's theater, the portrait escapes its essentially static nature and becomes a dramatically active part of the play. This transformation may be seen with reference to form. Molière's portraits are typically made up of two kinds of statements: static adjectival statements (what the individual is), and active ones, concerning what the character does (usually iterative). 
The first group is traditionally associated with the portrait form: "Mon père est d'une humeur à consentir à tout" (Les Femmes savantes I,iii,205); "C'est un homme, à la vérité, dont les lumières sont petites" (Le Bourgeois Gentilhomme 1,i); "C'est un vieux importun" (Les Fâcheux IIl,iii); etc. Philippe Hamon compares a portrait to a dictionary: in both cases one begins with a name, and seeks a definition. ${ }^{13}$ Indeed, such definitional statements (often signaled by the verb "être") are at the core of all portraits; in the examples we are considering, they generally precede statements concerning the object's actions. " "C'est in vieux importun," for example, is followed several lines later by: "Il fatigue le monde avec ses réveries" (Les Facheux IIl, iii). Although such repeated, generalized actions serve more to characterize the object of the portrait than to indicate the passage of time, they are nontheless more dynamic than "être" statements. They suggest movement, even if that movement is itself merely an endless repetition. Not surprisingly, action statements occur with great frequency in Molière's portraits: they follow but significantly outnumber "être" statements. The dynamism of his theater carries over even into this most static of discourses.

In keeping with this preference for action over stasis, physical description is not a regular feature of Molière's portraits. In fact, specific references to parts of the body appear in less than a quarter of the group. Of course, this relative paucity is in part due to the context of the discourse. In general, the objects of the portraits appear onstage; therefore, physical description would seem redundant. Practical considerations of stagecraft also arise: physical description within the spoken text might limit the options of the dramatic practitioners in choices of casting, costume, and make-up. Perhaps in response to such concerns, many of the physical references found in Molière's theater are either fairly vague ("sa personne" appears seven times), ${ }^{15}$ or else concern facial details which would be relatively difficult for the spectator to perceive ("Il a l'oreille rouge et le teint bien fleuri," Tartuffe Il,iii,647; "vos lèvres appétissantes," Le Mariage forcé sc. 2; etc.). Such physical details seem to complement the visual channel rather than to limit or repeat it.

This is not to say, however, that the function of the portrait is divorced from stagecraft. Perhaps the most specifically theatrical function of the portrait is to provide the performers with a sense of how a character is to be played. Such communication between author and dramatic practitioner might be expected to take two forms: first, the playwright might present a nondramatic portrait within the didascalia, the stage directions. ${ }^{16}$ This technique was not utilized by Molière. There is only one such example in all of his theater, and it is brief: "Thomas Diafoirus est un grand benêt, nouvellement sorti des Ecoles, qui fait toutes choses de mauvaise grâce et à contretemps" (Le Malade imaginaire, II,v). Even this single instance seems curious, because it contributes very little information which is not already obvious from the dialogue. The second form of communication to the practitioner is through inscribed performance. Indicators are embedded within the dialogue and serve to limit and guide the performance. These indicators may be inscribed explicitly through physical description, or implicitly, by the description of typical actions. Elise, for example, in her lengthy portrait of Climène, says: "ll semble que tout son corps soit démonté, et que les mouvements de ses hanches, des ses épaules et de sa tête n'aillent que par ressorts. Elle affecte toujours un ton de voix languissant et niais, fait la moue pour montrer une petite bouche, et roule les yeux pour les faire paraître grands" (Critique de l'Ecole des femmes, sc. 2). Climène's movements, tone of voice, and facial expressions are all clearly set out.

The most common function for a portrait within a Molière play is to introduce a character. Such introductions are usually for the benefit of the audience, which explains why portraits are so frequently found in the first act. Typical is Sganarelle's portrait of Dom Juan: " . . . je t'apprends, inter nos, que tu vois en Dom Juan, mon maître, le plus grand scélérat que la terre ait jamais porté, un enragé, un chien, un Diable, un Turc, un Hérétique, qui ne croit ni Ciel, (ni saint, ni Dieu), ni loup-garou, qui passe cette vie en véritable bête brute, en pourceau d'Epicure, en vrai Sardanapale, qui ferme l'oreille . . . "(Dom Juan I,i). It is obvious that, although it is ostensibly addressed to Gusman, the portrait is above all told for the benefit of the spectator. It introduces Dom Juan, who will come onstage for the first time in the following scene. In Le Misanthrope, Célimène's portrait of Arsinoé presents the older woman to the audience (IIl,iii) and is followed, once again, by the character's arrival onstage.

Molière modifies the nature of the portrait to produce multiple onstage functions. Portraiture does not merely serve to introduce or describe its object; often the spectator learns almost as much about the speaker, the teller of the portrait. Octave's lengthy and hyperbolic description of his beloved Hyacinte (Les Fourberies de Scapin l,ii) primarily reveals Octave's personality and amorous state (Hyacinte, after all, plays only a secondary role in the play). The spectator is afforded a similar introduction to Mme Pernelle in the first scene of Tartuffe: within the first forty lines of the play, she tells five brief, caustic portraits of (and to) the members of her son's family and household. In this series of examples, the spectator's attention is focused perhaps equally on Mme Pernelle and on each of the objects in turn. She makes frequent references to herself ("i'ai prédit cent fois," "un train que je hais fort," "cet état me blesse," etc.; $1,1,18,24,29)$, and the very form of her portraits-brief and aggressive - alerts the spectator to her personality. By incorporating an implicit portrait of the speaker within the speaker's description of another character, the passage gains in dramatic potential as well as complexity. What the spectator learns about the speaker often casts doubt on the objectivity of the portrait and makes portrait-telling a more complex and ambiguous enterprise. 
Another of the multiple functions with which Molière endows the dramatic portrait is to broaden the restricted universe of the stage. A number of the objects of portraits are characters who never appear onstage. Some play roles in the action of the play (for example, the king in Tartuffe, V,vii,1906-16; Alceste's legal adversary, Le Misanthrope, 1,i,124-36). Others are merely types, individualized solely by a proper name. Dorine, for example, describes Orante, a woman whose virtue is the result of her advanced age and lack of suitors (Tartuffe, 1,i,124-40). She has no role in the play and serves merely as a model of social behavior about which Mme Pernelle and Dorine can disagree. Such portraits function to conjure up verbally a larger social context. The spectator's interest focuses not on the specific characters described, but rather on their status as representative of a group or class of individuals, a social universe beyond the confines of the stage. ${ }^{17}$

Molière does not, however, limit himself to introducing characters or even using portraits to enlarge the scope of a play. Often, the portraits are an active part of the interaction between characters, part of the onstage action. In Act III, scene iv, of Le Misanthrope, Arsinoé attacks Célimène with a report of what others are supposedly saying about her conduct. Célimène responds in kind, with a speech that closely parallels Arsinoe's. There is one important difference between the two, however: Célimène fumishes a portrait of her rival (924-44). ${ }^{18}$ The spectator hardly needs a portrait of Arsinoe at this point in the play (there was one of her in the previous scene). The objectivity of the passage is clearly secondary to its dramatic force: Célimène's desire to exact revenge on her critic. Her natural propensity for portrait-making serves her well hene; later, in the last act, it will lead to her disgrace.

There are many examples of this active, dramatic function in Molière's theater: M. Jourdain gives his wife a portrait of Dorante, the nobleman, in order to convince her of his great value as a friend (Le Bourgeois Gentilhomme III,iii); Sosie describes his double (Mercure) to Amphitryon in order to defend himself to $h$ is master (Amphitryon $11, \mathrm{i}, 783-87$ ); Sgana relle portrays Dom Juan in negative terms to Charlotte and Mathurine in order to warn them about his true motives (Dom Iuan II,iv). In Monsieur de Pourceaugnac we find a portrait of the eponymous character that is in fact a medical diagnosis of his supposed "ailment" (I,viii). The list is long, and each example is determined by, and acts within, the particular dramatic context in which it occurs.

The term "dramatic context" refers to the specific onstage situation: the conflicts, tensions, and alliances among the characters. It is thus crucial to consider to whom the portrait is addressed. M Jourdain, in the example above, tries to convince a wife who will not easily be convinced. His portrait of Dorante will thus be worded in such a way as to attempt to overcome her hesitations: objectivity thus becomes secondary to rhetorical ends.
"Dramatic context" may also apply to the more specifically dramaturgical elements of the speech situation. For example, is the particular portrait elicited by a question from the interlocutor? Is it presented in one block, or is it fragmented in the form of a dialogue? To the extent that a portrait is linked to such signs of dialogue, it will be more dramatic and, simultaneously, less of a discrete, static set-piece. The descriptions of Lysandre and Araminte in La Critique de l'Ecole des femmes are both initiated by leading questions from the marquis ("Dis-moi un peu, Chevalier, crois-tu que Lysandre ait de I'esprit?"; scene 5), as are each of Célimène's salon portraits (Le Misanthrope II,iv).

A large number of the portraits in Molière's plays are not merely situated within the context of a dialogue, but themselves employ the form of a dialogue. Sometimes the portrait is double-voiced: complementary or rival descriptions of the same character. Célimène, in Le Misanthrope, describes Alceste in ironic terms; Philinte then goes on and describes him further, echoing Célimène's portrait (Il,iv,669-86; see also Tartuffe, 1,i,121-40). The most striking example of this technique is in Le Bourgeois Gentilhomme: Cléonte, angry at Lucille, says to his servant, Covielle "fais-moi de sa personne une peinture qui me la rende méprisable; et marque-moi bien, pour m'en dégoûter, tous les défauts que tu peux voir en elle" (III,ix). Covielle obliges, but Cléonte repeatedly interrupts him, supplying his own positive portrait of Lucille in opposition to the negative images that his servant proposes. The result is a comic dialogue which underlines the subjectivity and limited truth value of all portraits:

COVIELlE: Elle, Monsieur! voilà une belle mijaurée, une pimpesouée bien bâtie, pour vous donner tant d'amour! Je ne lui vois rien que de très médiocre, et vous trouverez cent personnes qui seront plus dignes de vous. Premièrement, elle a les yeux petits.

CLÉONIE: Cela est vrai, elle a les yeux petits; mais elle les a pleins de feux, les plus brillants, les plus perçants du monde, les plus touchants qu'on puisse voir.

COVIELLE: Elle a la bouche grande.

CLÉONTE: Oui; mais on y voit des grâces qu'on ne voit point aux autres bouches; et cette bouche, en la voyant, inspire des désirs, est la plus attrayante, la plus amoureuse du monde. (IIl,ix)

The portrait has become a dialogue about the different ways in which any given trait can be interpreted, a heated and dynamic discussion between two characters onstage. The two intertwined and opposed portraits have become onstage dramatic acts. This dialogue technique used in conjunction with portraits is more frequent in the second half of Molière's career, and it generally involves one portrait-teller who is interrupted by the comments and questions of his/her interlocutor. Scapin, for example, repeatedly cuts 
into Octave's lengthy portrait of his beloved Hyacinte with ironic comments ("Je vois tout cela," "Je sais cela encore," "Je ne vois pas encore où ceci veut aller") which call attention to the inadequacy of Octave's speech as a subject for dialogue, while at the same time instituting a dialogue between the two onstage characters (Les Fourberies de Scapin l,ii). It is worth noting that no portraits are found within monologues; Molière consistently attempts to minimize the static nature of description and to exploit the potential for dramatic complexity that he recognized in the portrait form.

Molière at times varies the standard onstage context of portrait-telling to introduce further dramatic complexity. The norm is that character "a" describes to character " $b$ " a third individual, " $c$," who is absent during the telling. In a number of instances, Molière instead places the object of the description onstage (generally as the interlocutor) or has a character tell his/ her own portrait. Altering the standard situation for telling portraits generally has the effect of calling the objectivity of the description into ques. tion. Characters are far less likely to be disinterested in their description if the object of the portrait is onstage; self-portraits are especially unreliable. In either case, the portraitist has specific goals in recounting the description, and these goals often stand in sharp contrast to the pretensions of the standard portrait. Sganarelle, in a state of sexual delirium, delivers a highly physical portrait of his fiancée to her (Le Mariage forcé, scene 2); each of Mme Pernelle's brief portraits in the first scene of Tartuffe are addressed angrily to their object (13-40); Sbrigani describes Nérine and her talents to Julie, Eraste, and, most particularly, Nérine herself ("la gloire que vous acquîtes . . . ;" Monsieur de Pourceaugnac l,ii). The effect in the last example is also comic because Sbrigani juxtaposes a long list of crimes that the old woman has committed with a heroic vocabulary ("avec tant d'honnêteté," "avec tant de grandeur d'âme," etc.). These portraits are especially dramatic because of their strong onstage functions: Sganarelle wants to exult over his impending ownership of Dorimène's body; Mme Pernelle criticizes, and Sbrigani seeks to flatter.

The potential for appearance and reality to diverge widely in the case of self-portraiture presents an opportunity for comic effect which Molière exploits in several of his plays. The Cardinal de Retz is aware of this potential when, at the end of his "galérie," he raises the possibility of adding his own portrait to the series. He decides against doing so and says: "I'on ne se connaît jamais assez bien pour se peindre raisonnablement soi-même."19 The key word here is "raisonnablement": any self-portrait has the potential for being limited in its perspective and objectivity; and to further admit that the "unreasonable" is often funny suffices to reveal the comic subjectivity of the self-portraitist. Sganarelle, for example, describes himself to his wife in an attempt to convince her that he is an attractive husband:
Peut-on trouver en moi quelque chose à redire? Cette taille, ce port que tout le monde admire, Ce visage si propre à donner de l'amour,

Pour qui mille beautés soupirent nuit et jour;

Bref, en tout et partout, ma personne charmante

N'est donc pas un morceau dont vous soyez contente?

(Sganarelle sc. vi, 165-70)

The comic effect is compounded in this example by the word "morceau" which both subverts the lofty tone of the first five lines and over-"objectifies" the object of the portrait. In Le Mariage forcé, Sganarelle tells a similar self-portrait to his friend Géronimo, here accenting his attractiveness as a potential husband (scene 1). Acaste also indulges in self-praise as he describes himself at some length to Clitandre (Le Misanthrope 111,1,781-804). The spectator laughs because of the fatuity of the speakers; not only does the audience appreciate the discordance between the portrait and reality, but there is invariably a character onstage who also perceives the limited truth value of the self-portrait. Even the equally fatuitous Clitandre responds to Acaste's description of himself with irony: "Oui; mais, trouvant ailleurs des conquêtes faciles, / Pourquoi pousser ici des soupirs inutiles?" (805-06). The spectator is thus alerted to distrust the portrait. In a more complicated, although less amusing, formulation of the same situation, Tartuffe responds to Damis's accusations that he made advances to Elmire with a two-part self-portrait for Orgon's benefit. In it, he paints himself in the blackest of terms: "Oui, mon frère, je suis un méchant, un coupable . . ." (Tartuffe III,vi, 1074-82 and 1097-1104). The spectator and Damis both know that he is in fact telling the truth; but the truth is so exaggerated that Orgon can interpret the self-portrait only as a series of lies motivated by his friend's extreme humility. If the audience fails to laugh, it is because it senses danger; Tartuffe is strong and intelligent. Orgon's credulity is in fact funny, but it is overshadowed by. Tartuffe's manipulative power.

Generally, then, the portraits found in Molière's theater can be said to have one or more of these broad basic functions: exposition of character (for spectator and performer), broadening of the dramatic universe, highlightingdifferences between appearance and reality, and as a source of dramatic action. Molière demonstrates great flexibility in his use of portraits adapting this seemingly nondramatic form to a broad variety of dramatic situations. As his career progressed, Molière experimented increasingly, giving portraits the form of dialogue and undermining their traditional objectivity. The function of introducing a character becomes secondary or almost tongue-in-cheek, as in the cases of the descriptions of the young and beautiful Mariane (L'Avare, I,ii) and Hyacinte (Les Fourberies de Scapin, I,ii), or 
the gratuitously long portraits of Sbrigani and Nérine in Monsieur de Pourceaugnac $(\mathrm{I}, \mathrm{ii})$, while the dramatic and comic functions play a far greater role. Two of Molière's masterpieces, Tartuffe and Le Misanthrope, revolve around portraits. In the first case, Tartuffe does not appear until the third act. Until his entrance, and even later when he is not onstage, much of the dialogue focuses on him, in an attempt (or perhaps an intentional failure) to come to an understanding of who and what he is, through a series of more or less unified portraits. In a sense, the entire play is a portrait of Tartuffe. In Le Misanthrope, portraits play an extensive and varied role: Célimène is a master of the genre, and much of the activity in her salon involves portraits, both written and oral. She is not alone in this, however, as many of the characters, including Alceste, share her skill at portraiture. Here, unlike in Tartuffe, the objects of description are of secondary interest and the focus is rather on the speaker and interlocutor as objectivity is sacrificed to dramatic rhetorical ends.

By and large, portraits are smoothly integrated into the dramatic action of Molière's plays. Rarely do they stand out as awkward, alien passages. Occasionally, however, Molière chooses to underline their presence. He calls attention to them either by direct reference to the passage ("Dieu me damne, voilà son portrait véritable," Le Misanthrope, II,v,649), or, more insistently, by the use of multiple portraits in a series. We find several such series: the most obvious, of course, is Célimène's "galérie de portraits," which is complemented in the last scene of Le Misanthrope by the brief descriptions of the Vicomte, Acaste, Alceste, Oronte, and Clitandre that are read aloud from her letters. Tartuffe opens with Mme Pernelle's five brief portraits of and to the members of her son's household. Finally, there is a group of six portraits in L'Impromptu de Versailles, in which Molière, playing himself, describes the characters that the actors in his troupe are to play. L'Impromptu, of course, is meta-theater, a play which calls constant attention to itself as theater. Thus, it is not surprising to find, in that context, a series of portraits whose subject is so expressly dramatic: dramatic roles and how they should be played.

While this is far from an complete examination of the portrait in Molière's theater, it is nonetheless already clear that it is a flexible and yet complex dramatic structure. It provides psychological depth for characters, presenting interior and exterior traits, and for the spectator (as opposed to the reader) sets up the juxtaposition of the verbal character and his physical counterpart onstage. As Erica Harth puts it, the physical and the verbal are prolongations: text and image reproduce each other. ${ }^{20}$ Furthermore, by calling the objectivity of the portrait into question, in the various ways we have examined, Molière in fact alters the whole notion. No longer is a portrait necessarily referential, nor is it simply static. It becomes both dynamic and problematic, calling attention to Molière's dramatic mastery. The comedy of Molière's portraits comes, in part, from the fact that the spectator/reader is disturbed by the arbitrary nature of the relationship between the portrait and its model.

TRINITY UNIVERSITY

1. La Critique de l'Ecole des femmes, sc. 6 . The edition used for this and all other citations of Molière's text is Georges Couton, CEuvres complètes, 2 vol. (Paris: Gallimard, 1971).

2. Jacques Schérer, for example, in La Dramaturgie classique en France, devotes sixteen pages to récits, but does not discuss portraits as a standard feature of the classical theater (Paris: Nizet, 1956). Gabriel Conesa does devote a brief section of his book to portraits in Molière's theater, but leaves a number of issues unexamined (Le Dialogue moliéresque; étude stylistique et dramaturgique, Paris: Presses Universitaires de France, 1983, pp. 33-43)

3. Robert E. Hill, "Figurae Verborum in Retz's Portraits," Texas Studies in Literature and Language 13 (1972), 571.

4. Both Boursault and De Visé describe Molière as the "peintre" in their critiques of his theater. See René Bray, Molière homme de théâtre (Paris: Mercure de France, 1954), p. 265.

S. Philippe Hamon, "Pour un statut sémiologique du personnage," Littérature 6 (1972), 86-110; spt. in Poétique du récit (Paris: Seuil, 1977), p. 178, n. 73.

6. On the subject of the roots of the literary portrait, see E. Heier," "The Literary Portrait" as a Device of Characterization," Neophilologus 60 (1976), 321; Erica Harth, Ideology and Culture in Seventeenth-Century France (Comell University Press, 1983), p. 100; and René Bray, La Préciosité et les précieux (Paris: Nizet, 1945), p. 189.

7. For discussions of the importance of the proper name to the notion of character, see Roland Barthes, S/Z (Paris: Seuil, 1970), pp. 101-02; Seymour Chatman, Story and Discourse (Cornell University Press, 1978), p. 131.

8. Portraits generally avoid extremes of brevity and length. A portrait sums up the personality of an individual; thus a single trait is not sufficient. The other extreme is equally problematic: a portrait of more than a couple of pages in length becomes unwieldy, perhaps because of the absence of narrative. One might consider biography (or autobiography) to be a form of extended portrait. However, what makes a biography eminently readable is that it is a narrativized portrait. At the same time, it is worth noting that portraits, like all forms of description, have no natural limits, no necessary points of closure (beyond conveying a sense of completion, but at what point can one say that a description or a portrait is complete?). Philippe Hamon discusses the issue of the uncontrollable freedom of the descriptif in his Introduction dl'analyse du descriptif (Paris: Hachette, 1981), p. 15.

9. Harth, p. 69. The following discussion of literary portraits in seventeenthcentury France owes much to her excellent study.

10. Harth, pp. 70-75. Portraits also served a practical function: Derek A. Watts recounts that Venetian ambassadors used written portraits to keep their superiors advised of the personalities of the court where they were assigned (Cardinal de Retz. The Ambiguities of the Seventeenth-Century Mind, Oxford University Press, 1980, p. 229).

11. Portraits, perhaps because of their claims to objectivity, are most often associated with the work of the memorialists. In his Mémoires, the Cardinal de Retz 
describes seventeen of his contemporaries in what he calls a "galérie de portraits," set apart from the narrative (Mémoires, eds. Maurice Allem and Edith Thomas, Paris: Gallimard, 1956, pp. 154-60). These portraits are elegant, often cruel, and unusual in that they contain no physical description of their objects. Saint-Simon's Mémoires, although written in the next century, are full of portraits in largely the same tradition as Retz's. Saint-Simon, however, made extensive use of the physical features of his objects, seeing in the physical an extension and a reflection of the individual's moral qualities (Henry Amer, "Littérature et portrait. Retz, Saint-Simon, Chateaubriand, Proust," Etudes françaises 3 [1967], 146). With La Bruyère's Caracteres (1688), published well after Molière's death (1673), the portrait undergoes its final transformation and becomes a classical genre, focusing on the general and the universal rather than on the particular. The objectivity of the portrait is no longer verifiable, tied to some particular reality, because La Bruyère describes types, not individuals. In fact, a case can be made that the Caracteres are not portraits at all.

12. As Jacques Guicharnaud suggests in his Molière, une aventure théâtrale (Paris: Gallimard, 1963), pp. 24-25.

13. Hamon "Pour un statut sémiologique du personnage," p. 75 , note 51 . See also A. Kibédi Varga, "Antithèse et synonyme," Poetique 4 (1973), 308.

14. Conesa speaks of the two phases of Molière's portraits: first the static and then the dynamic; p. 40.

15. The expression "(sa) personne" appears in Sganarelle sc. 6, 1.169; Tartuffe II,ii,502; II, iii,646; Le Misanthrope V, iv; Les Fourberies de Scapin I, ii; Le Malade imaginaire I,iv; I,v.

16. In the classical theater, didascalia are rare, and information which might be expected to appear in that form is often incorporated directly in the dialogue (e.g., the famous example from Phedre: "Que ces vains ornements, que ces voiles me pésent!"; I, iii).

17. There is another series of passages which are very similar to these portraits: descriptions of groups rather than individuals ("jeunes muguets," L'Ecole des maris I,i, 24-38; "les jaloux" and "les non-jaloux," Les Fâcheux Il,iv, 416-40; "les maris patients, " L'Ecole des femmes I,i, 25-42; etc.). Obviously similar to portraits, they are differentiated by the plurality of their object and by the absence of a proper name. These are not individuals who might walk onstage at any time, but faceless, uniform groups, representing the social context in which the action of the play occurs. By far the greatest number of these group portraits is found in $L^{\prime}$ 'Ecole desfemmes; Arnolphe describes not only "les maris patients," but also "les damoiseux" and "les femmes habiles," while Chrysalde paints "les maris trop accommodants," those "qui se plaignent d'être cocus," and "les femmes de bien" (I,i, 25-42; III,i,651-56; IIl,iv, 82032; IV, viii, 1252-59, 1263.67, 1294-1301). The use of group portraits serves to underscore both Amolphe's hubris and his paranoia. He is in conflict, not with a specific, identifiable individual, but with entire groups of men and women, and he intends to best them all. Both group portraits and those which describe named characters who do not appear onstage provide a significant means of broadening the physical space and the social context of the play.

18. Jacques Truchet suggests that Célimène's speech in this scene is not as carefully constructed as Arsinoé's, because she has not had time to prepare it ("Molière et le procédé du dialogue dans le dialogue. Style direct et style indirect," Travaux de linguistique et de littérature 13, no. 2 [1975], 253). On the contrary, I would argue that Célimène shows her superionity over her rival by the rapid and skillful addition of a portrait of her interlocutor to the pastiche of Arsinoe's speech.

19. Cardinal de Retz, p. 160

20. Harth, pp. 77,81 . 